\title{
EL ESPACIO DE LA MARGINALIDAD: MEDEA EN OVIDIO Y EN SÉNECA
}

\author{
Nazira Álvarez Espinoza
}

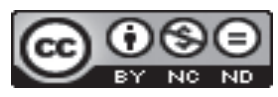

Doi: https://doi.org/10.15517/rfl.v46iEspecial.41498

URL: https://revistas.ucr.ac.cr/index.php/filyling/index 



\title{
EL ESPACIO DE LA MARGINALIDAD: MEDEA EN OVIDIO Y EN SÉNECA
}

\author{
THE MARGINALITY SPACE IN \\ SENECA'S AND OVID'S MEDEA
}

\author{
Nazira Álvarez Espinoza
}

\begin{abstract}
RESUMEN
El artículo realiza una aproximación desde una perspectiva de género y los estudios geográficos al personaje mítico de Medea en los textos de Ovidio Heroidas y Metamorfosis y la Medea de Séneca. El análisis comprende los conceptos de espacio y marginalidad femenina desde los espacios físicos y simbólicos donde se establecen las relaciones sociales y culturales a partir de las identidades y la ideología en la Roma imperial.

Palabras clave: tragedia romana; marginalidad; Medea; espacio femenino; Séneca.
\end{abstract}

\begin{abstract}
The paper develops an approach to the mythical character of Medea from a gender and geographic studies in Ovid's and Seneca's works. The analysis includes the concepts of space and symbolic and physical space related to female that contributes to establish social and cultural relations of identity and ideology in imperial Rome.

Keywords: roman tragedy; marginality; Medea; feminine space; Séneca.
\end{abstract}

\section{Introducción}

En Grecia y Roma los espacios de género fueron delimitados en función del sexo y definidos socialmente. Sin embargo, es importante señalar que estos no fueron lugares estáticos, sino flexibles y permeables, donde la organización espacial y jerárquica de hombres y mujeres intersectó la esfera pública y el hogar. En este sentido, aunque ambos sexos compartieron ambientes privados y políticos, se instituyó un comportamiento diferenciado a partir de los roles de género. Así, ambos interactuaron en función de normas que determinaban las acciones y el comportamiento en las esferas del ámbito material y simbólico. La marginalidad femenina

M. L. Nazira Álvarez Espinoza. Profesora de la Escuela de Filología, Lingüística y Literatura. Universidad de Costa Rica. Costa Rica.

Correo electrónico: nazira.alvarez@ucr.ac.cr

Recepción: 20- 06- 19

Aceptación: 09- 12- 19 
se situó en la periferia al limitar los derechos y la ciudadanía de las mujeres. Ellas fueron excluidas de las jerarquías jurídicas y políticas, mientras que los varones ejercieron el poder como centro en la sociedad.

El objetivo de la presente investigación es analizar la marginalidad como espacio cultural de exclusión social del personaje de Medea por su condición de mujer y extranjera, en los textos de Ovidio Heroidas y Metamorfosis, y en la tragedia Medea de Séneca. En el primer apartado, se hace un breve recorrido por los antecedentes de los motivos literarios del mito en el mundo griego. El segundo apartado comprende un acercamiento a la marginalidad como espacio femenino en la Roma imperial. Finalmente, el tercer apartado estudia la marginalidad de Medea como espacio de exclusión en los textos de Ovidio y Séneca, con el fin de evaluar las acciones y los motivos que determinan la alteridad de Medea en relación con los valores y normas del mundo romano.

\section{Medea en los textos literarios de Grecia}

La primera mención sobre el personaje mítico de Medea se presenta en los textos de la literatura griega arcaica. En la Teogonía de Hesíodo (siglo VIII a. C.) se cita la genealogía divina de la hija de Eetes (2018, vv. 956-962):

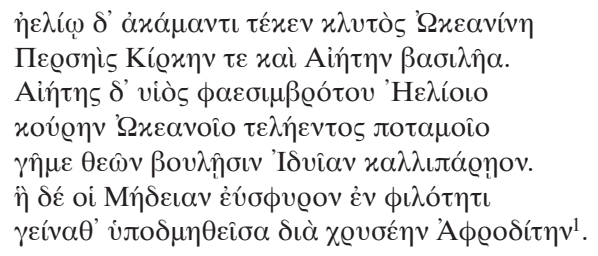

Desde un primer momento, el origen de Medea la separa de las mujeres mortales por su origen divino. Los progenitores son divinidades menores, descendientes de principios acuáticos y uranios. En el poema, también se menciona la visita de Jasón a la Cólquide, la abducción de la joven, la unión con el héroe helénico y el regreso a Yolcos (Teogonía, 2018, vv. 956-961):

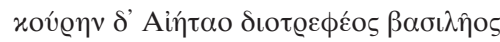

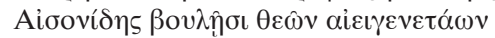

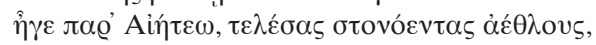

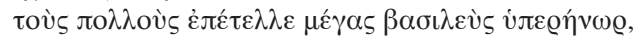

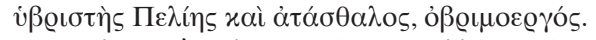

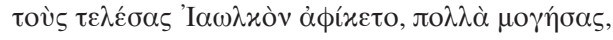

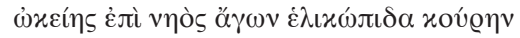

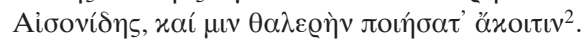

1 Con el incansable Helios, la ilustre Oceánide Perseis tuvo a Circe y al rey Eetes, hijo de Helios que ilumina a los mortales, se casó con una hija de Océano, río perfecto, por decisión de los dioses, con Idía de hermosas mejillas. Ésta parió a Medea de bellos tobillos. (Hesíodo, Teogonía, 1997).

2 A la hija de Eetes rey vástago de Zeus, el Esónida, por decisión de los dioses sempiternos, se la llevó del palacio de Eetes al término de las amargas pruebas que en gran número le impuso un rey poderoso y soberbio, el violento, insensato y osado Pelias. Cuando las llevó a cabo, volvió a Yolcos el Esónida, tras muchos sufrimientos, conduciendo en su rápida nave a la joven de ojos vivos y la hizo su floreciente esposa (Hesíodo, Teogonía, 1997, vv. 991-1000). 
De esta forma, a partir del relato teogónico se teje un hilo que une a Medea con la Hélade. Si bien es cierto, ella posee un origen divino en las primeras narraciones del mito, aún no menciona la relación de la joven con la magia.

En el siglo VI a. C., en lírica coral arcaica, la Pítica IV de Píndaro introduce nuevos motivos al mito de Medea. El poeta lírico enfatiza en la oda el carácter de extranjera, profetisa y maga del personaje. Él la identifica como "princesa de los colcos", con un "hálito de su boca inmortal” apta para profetizar el futuro (1997, vv. 9-13):

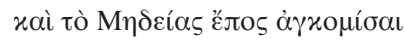

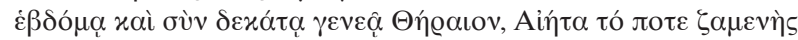

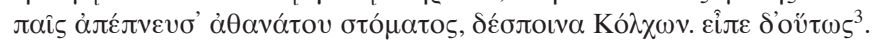

Además, este autor la señala como transgresora de la autoridad paterna, una maga poderosa que ayuda al héroe heleno a superar las pruebas (Píndaro, 1997):

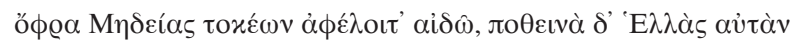

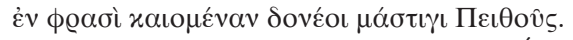

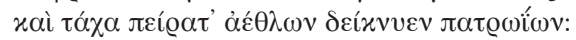

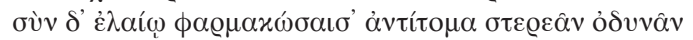

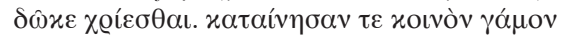

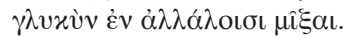

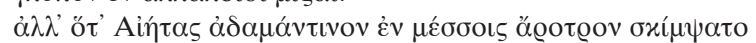

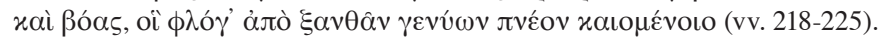

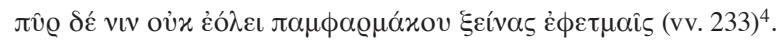

El poema singulariza el origen colco de la joven, el carácter oracular, el irrespeto a la autoridad paterna, el asesinato y la hechicería. En la aventura con Jasón, todos estos elementos la separan de la colectividad por su genealogía, poderes y acciones.

Eurípides tragediógrafo ateniense del siglo $\mathrm{V}$ a. C. realiza una reelaboración del mito donde por primera vez aparece Medea como asesina de su progenie cuando ella afirma de forma tajante (Eurípides, 1925, vv. 1236-1239):

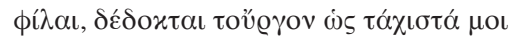

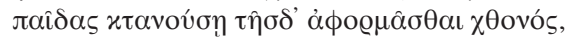

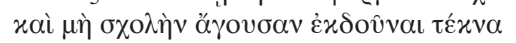

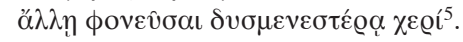

3 “y que de Medea el oráculo cumpliría en la decimoséptima generación, el oráculo pronunciado sobre Tera, aquel que un día la hija animosa de Eetes con el hálito dio de su boca inmortal, ella princesa de los colcos" (Píndaro, Pítica, IV, 1995).

$4 \quad$ El pájaro del delirio trajo por vez primera a los hombres, y conjuros y voces de encanto enseñó al hijo prudente de Esón, al fin de que Medea despojara del respeto a sus padres, y que la pasión por Grecia a ella -en sus entrañas abrasadas- agitara el látigo de la Persuasión. Y pronto le indicaba los críticos puntos de las pruebas paternas. Y con un aceite preparando remedios de hierbas cortadas contra fieros dolores, se los dio para ungirse. Y se prometieron en matrimonio común y dulce unirse uno con otro (Píndaro, Pítica, IV, 1995).

"Y el fuego no le arrollaba por los hechizos de la extranjera experta en toda magia" (Píndaro, Pítica, IV, 1995).

5 "Amigas, mi acción está decidida: matar cuanto antes a mis hijos y alejarme de esta tierra; no deseo, por vacilación, entregarlos a otra mano más hostil que los mate" (Eurípides, Medea, 1985). 
La tragedia Medea (431 a. C.) se sitúa en Corinto, donde la joven de la Cólquide es la esposa de Jasón y la madre de sus hijos. El conflicto en la tragedia surge ante la inminente boda de la hija del rey de Corinto con el esposo de Medea, quien la abandona por un matrimonio políticamente más provechoso en Grecia.

Inicialmente, Medea aparece en escena como una simple mujer, que sale del encierro del oikós para relatar su desventura. La protagonista enuncia un discurso donde resume la situación de inferioridad y sumisión de las mujeres atenienses y extranjeras frente a los varones (Eurípides, Medea, vv. 214-266). Al denunciar de forma incisiva la situación típica de las atenienses, ella logra, inicialmente, el apoyo del coro de mujeres por su desventurada situación. Sin embargo, la nodriza ya desde los primeros versos nos anticipa el carácter impredecible de la mujer de la Cólquide (Eurípides, 1925, vv. 36-40):

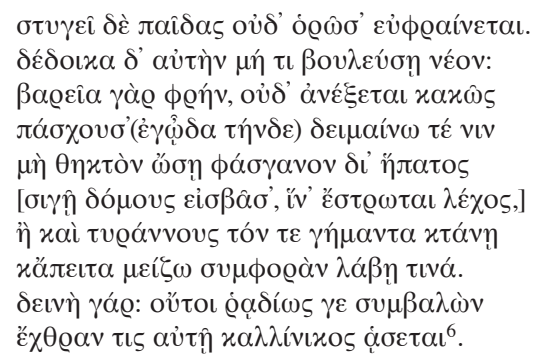

Una vez es repudiada, la hija de Eetes carece de cualquier reconocimiento social, es una bárbara exiliada sin estatus reconocido en el Ática. Además, al haber traicionado a su padre y a la patria debe abandonar la Cólquide. Medea actúa de forma voluntaria cuando elige vengarse de su marido por medio del asesinato de sus hijos. Las acciones que ella lleva a cabo en Corinto la convierten en una figura anti-natural y temible aislada de la colectividad (Eurípides, 1925, vv. 1336-1344):

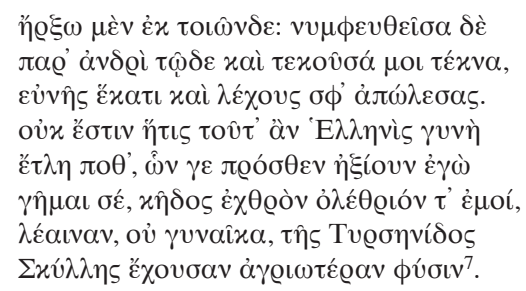

La recriminación final del esónida resume la otredad de Medea al afirmar que no existe una mujer griega capaz de atentar contra la progenie por venganza (Eurípides, 1925, vv. 1329-1333):

6 La infortunada aprende, bajo su desgracia, el valor de no estar lejos de la tierra patria. Ella odia a sus hijos y no se alegra de verlos, y temo que vaya a tramar algo inesperado, [pues su alma es violenta y no soportará ultraje. Yo la conozco bien y me horroriza pensar que vaya a clavarse un afilado puñal a través del hígado, entrando en silencio en la habitación donde está extendido su lecho, o que vaya a matar al rey y a su esposa y después se le venga encima una desgracia mayor], pues ella es de temer. No será fácil a quien ha incurrido en su odio que se lleve la corona de la victoria (Eurípides, Medea, 1985).

7 Así comenzaste tus crímenes. Habiéndote casado después conmigo y dado hijos, por celos de un lecho y una esposa los mataste. No existe mujer griega que se hubiera atrevido a esto y, sin embargo, antes que con ellas preferí casarme contigo - unión odiosa y funesta para mí- leona, no mujer, de natural más salvaje que la tirrénica Escila (Eurípides, Medea, 1985). 


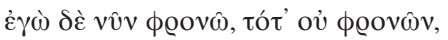

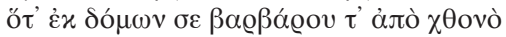

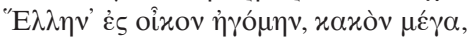

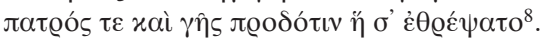

Johnston y Clauss (1997) confirman que tal transgresión convierte la imagen de madre asesina de sus hijos en el motivo que más interesó a autores posteriores. La posibilidad de apropiarse de la progenie por una mujer bárbara desestabiliza una de las principales bases sobre las que se construye la sociedad: las madres nutren a los hijos, son sus protectoras naturales. En la tragedia, el origen extranjero, la hechicería y el asesinato de la progenie son mostrados como elementos propios de la etnia bárbara de la protagonista.

Durante la época helenística, en el texto de Apolonio de Rodas las Argonáuticas (III a. C.), Medea se presenta como una doncella capaz de invocar a Hécate (Arg., libro IV, v. 110), dominar las fuerzas de la naturaleza (Arg., libro III, vv. 528-33), y hacer gemir al titán Prometeo (Arg., libro III, vv. 865-66). La furia de la princesa puede incluso destruir solo con la mirada al gigante de bronce Talos (2009, libro IV, vv. 1670-1671):

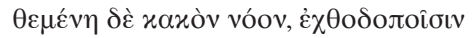

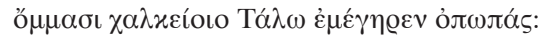

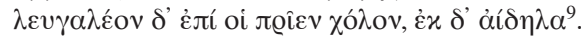

La hechicería de Medea es ampliamente desarrollada en el libro III de las Argonáuticas. En este texto, ella es presentada como experta en pociones y con el poder para dominar las fuerzas de la naturaleza (Apolonio, 2009):

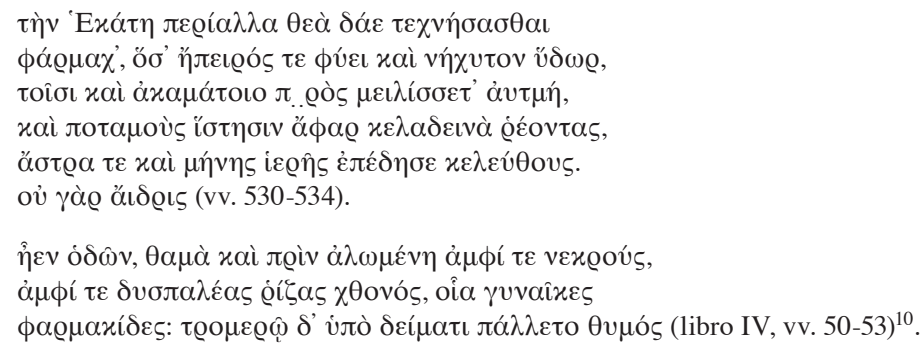

Apolonio no anticipa los futuros crímenes de Medea, pero la presenta situada como otredad para los helenos por su relación con las artes oscuras. Medea es colocada en un espacio liminal al abandonar la Cólquide. A partir de ese momento, después de la traición a su

8 "Ahora he recuperado la cordura que entonces no tuve, cuando, desde tu casa y desde tu país extranjero, te traía a una casa griega, enorme desgracia traidora a tu padre y a la tierra que te crió" (Eurípides, Medea, 1985).

9 "Revistiéndose de un espíritu perverso con ojos maléficos hechizó la mirada del broncíneo Talos. Masticaba contra él su terrible cólera y le arrojaba siniestras alucinaciones, en su violenta furia" (Apolonio, 1996).

10 En el palacio de Eetes vive una joven, a quien la diosa Hécate ha enseñado especialmente a preparar cuantas pócimas produce la tierra y el abundante agua.Con ellas incluso aplaca el aliento del infatigable fuego, y detiene al momento los ríos de rumorosas corrientes, y encadena los astros y los sagrados cursos de la luna (Apolonio, 1996, libro III).

"No desconocía los caminos, que también a menudo vagaba en busca de cadáveres y maléficas raíces de la tierra como acostumbran las hechiceras" (Apolonio, 1996, libro IV). 
familia, vivirá en el exilio. La unión con Jasón se convierte en la única protección que tendrá fuera de la Cólquide.

\section{Marginalidad femenina como espacio social en la Roma Imperial}

\subsection{Alteridad, marginalidad, identidad y cultura social}

El espacio en la literatura comprende no solo el físico-geográfico, sino también el social. Lefebvre (1979) en su aproximación al espacio como producción social propone la teoría del espacio social, el cual emerge a partir de la interacción de tres conceptos: práctica espacial, la localización actual y los movimientos característicos de una sociedad que se encuentran arraigados a partir de la repetición contínua. En este sentido, Rusell (2011) comenta:

Each exceptional space is, in its own, a herotopia. Such heterotopias, which represent, invert, and contest the assumed normative space which surrounds them, must also be, in Lefebvre's terms, representational spaces, individual spaces in which larger portions of social spaces can be encoded (p. 2) ${ }^{11}$.

En relación con los espacios y lugares es importante señalar la aproximación de Massey (2001): “The hegemonic spaces and places which we face today are not only products of forms of economic organization but reflect back at us also -and in the process reinforceother characteristics of social relations, among them those of gender"12 (p. 183). Por su parte, Featherstone, Hepworth y Turner (1993) enfatizan la importancia que tiene la construcción de los espacios para los seres humanos con su tendencia a producir y crearlos. Así, se perciben, ubican o dibujan de una forma simbólica o material, los límites que se establecen en los diferentes espacios, siempre en función de las expectativas de los otros.

En la Roma imperial, Ovidio y Séneca reelaboraron la representación del mito de Medea en sus textos literarios. Los autores citados hicieron hincapié en la condición de mujer extranjera del personaje mítico y su conducta transgresora. De esta forma, los autores la situaron en el espacio social de la marginalidad por su género, etnia y acciones. Así, lograron crear una imagen de la princesa de la Cólquide con un comportamiento fuera de control asociado a la barbarie en la cultura romana.

Para Grahame (1998), el concepto "cultura" forma parte de un proceso subjetivo, mediante el cual los individuos se reconocen como pertenecientes a un grupo determinado que los diferencia de otros. En este sentido, cada sociedad posee normas, valores e ideas que guían su comportamiento. La identidad social se establece en relación con ese sentido de pertenencia; desde esta perspectiva, Grahame (1998) señala cómo este concepto comprende diferentes aspectos:

First, we might recognize a social identity, which includes such relationships as family ties, personal networks of friends and other associates, peer group membership, class allegiance, social status, and the like. Second, we might

11 Cada espacio excepcional es en sí, una herotopia. Tales heterotopias representan, invierten y enfrentan con la normativa asumida en relación con el espacio que los rodea, la cual debe ser, en términos de Lefebvre, espacios representacionales, espacios individuales en los cuales mayor cantidad de espacios sociales pueden ser codificados (traducción propia).

12 Los espacios y lugares hegemónicos que encontramos hoy día no son solo producto de las formas de organización económica, sino que también reflejan -y en el proceso refuerzan- otras características de las relaciones sociales, entre ellas las de género (traducción propia). 
identify a political identity, which would include such aspects as citizenship, membership of a body politic, party affiliation and nationality. A specifically cultural identity, in other words ethnicity, requires the self-conscious recognition by a group of individuals of commonalities that emerge through their conformity to similar ways of acting and being. These are likely to be expressed through the possession of similar cultural traits, such as language, styles of dress, personal adornment, material objects and particular ways of behaving (p. 159) ${ }^{13}$.

Así pues, la relación entre identidad social, política y cultural incluye elementos que suponen las relaciones interpersonales de los individuos, la pertenencia a un espacio geográfico determinado y la etnia. A partir de estos conceptos se construye la identidad y la alteridad. Los conceptos de identidad y alteridad que reseña Morales (2012) resultan de gran utilidad para entender cómo se encuentran relacionados:

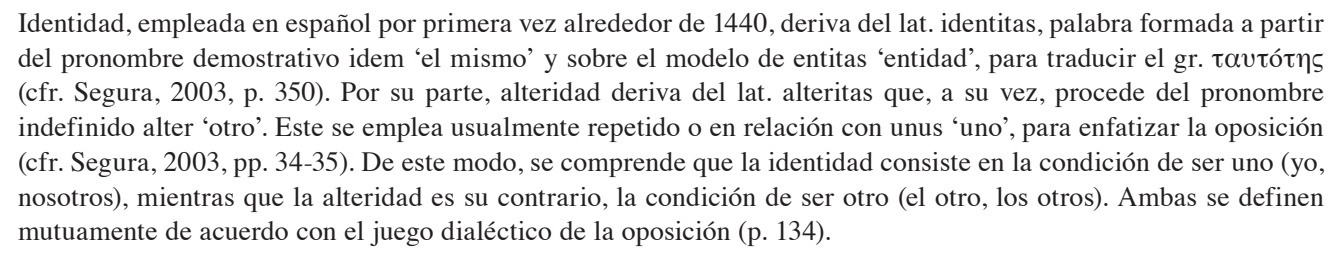

Esta oposición también se entreteje con los márgenes, en la medida en que las identidades reflejan -de acuerdo con Jenkins (2004)-, cómo los individuos y los grupos internalizan y establecen las categorías sociales en el entorno. Así, se conforman las identidades culturales, étnicas ${ }^{14}$, de género y clase social al definir la ideología en relación con el ser y la otredad de los diferentes grupos en la sociedad. La inclusión y evolución de la perspectiva de género, en las disciplinas geográficas, ha permitido introducir líneas de trabajo y bases teórico-metodológicas de las ciencias sociales y humanas ${ }^{15}$.

El género juega un papel esencial en la formación de los espacios físicos, simbólicos y conceptuales. De acuerdo con Foxhall y Neher (2011), el género se convierte en un elemento fundamental de las identidades humanas, las relaciones sociales, y el entramado político, económico e ideológico. Por su parte, Mirón (2014) señala que las prácticas y las ideologías de género se manifiestan en espacios físicos y simbólicos, como una pieza esencial e inseparable del modo en cómo se organiza una sociedad. Las relaciones entre género, sexualidad y espacio van más allá de una simple división binaria entre lo público y lo privado. Como consecuencia de lo anterior, las esferas de acción de la masculinidad y la feminidad influyen en la conformación de las identidades sociales.

13 En primer lugar, podemos reconocer la identidad social, la cual incluye relaciones como lazos familiares, redes personales de amistades y otros asociados, la pertenencia a un grupo de iguales, alianzas de clase, estatus social y semejantes. En segundo lugar, podemos identificar una identidad política, la cual incluiría aspectos tales como ciudadanía, membresía a un cuerpo político, afiliación a un partido y nacionalidad. Una identidad cultural específica, en otras palabras, etnicidad, requiere el reconocimiento autoconsciente por parte de un grupo de individuos de puntos en común que surgen a partir de su conformidad en relación con formas similares de ser y actuar. Estas son probablemente expresadas a través de la posesión de rasgos culturales similares, tales como el lenguaje, tipo de vestimenta, adorno personal, objetos materiales y formas particulares de comportamiento (traducción propia).

14 Entendida aquí como la identidad étnica que alude a los rasgos culturales comunes a un grupo.

15 Al respecto ver entre otros: Sabaté (1984), Díaz (1995), Caballé (1997) y Vicente (2000), citados en Lindón y Hiernaux (2006); McDowell (2003), Sidaway (2004) y Sharp (2005), citados en Johnston (2005); Del Casino (2009). 
Los símbolos establecidos por la colectividad de una cultura y época determinadas, como enfatiza McDowell (citado en Johnston, 2005), diferencian las jerarquías sociales. Los hombres y las mujeres, a partir de los roles de género, reciben un tratamiento diferenciado como individuos y miembros de la colectividad. Además, la organización social en las diversas épocas y culturas define las identidades en función de lo que se considera autóctono o foráneo. La pertenencia a un grupo y a un ámbito geográfico particular prescriben la ideología que sitúa a los sujetos como nativos o extranjeros. La identidad cultura ${ }^{16}$ ligada a un espacio geográfico determinado, fija la jerarquía de centro en las sociedades para los ciudadanos y ubica como margen a los sujetos considerados extranjeros. Petts (1998) enfatiza al respecto:

Cultural identity can be defined as the means of centering individuals in relation to geographical and cosmological space, although within each society different elements may create different myths of being and cultural identity may often be contested. Cultural identity should not be separated from other forms of social identity (p. 80$)^{17}$.

Precisamente, al establecer las divisiones antes citadas se funda una marginalidad como lugar fuera del centro que se constituye en un espacio simbólico en la periferia. Este es el lugar donde se separa a los ciudadanos de los extranjeros, de las mujeres y de los esclavos en función de las creencias y valores que distinguen y separan a unos de otros. Por esta razón como señala Ayala (2015):

Si una persona se siente "dentro" en términos territoriales, a su vez se siente segura y no amenazada, protegida y no expuesta. Por otro lado, si se siente separada o alejada, la persona desarrolla de alguna forma una especie de división o separación entre ella y el mundo (p. 176).

En Roma la domus se constituyó en el espacio destinado para ejercer las funciones asociadas con el matrimonio, la maternidad y la feminidad. Meyers (2003) enfatiza que los sujetos son productos de la sociedad en la que viven y en la cual ocupan una posición que responde al lugar asignado por el grupo hegemónico que rige este espacio. A las mujeres les correspondió ejercer el cuido del hogar y la educación de los hijos en el hogar, un lugar aislado de la política. La casa fue el espacio simbólico de lo invisible, el silencio y la alienación.

\subsection{La marginalidad como espacio social en Roma}

Las relaciones entre género, sexualidad y espacio van más allá de una división binaria entre lo público y lo privado, lo masculino y lo femenino; como enfatiza McDowell (2000):

Spaces have different meanings for different groups, and each space may, over the course of a day, a week or longer, be occupied by a series of different social groups whose practices include the same spaces with different meanings at different times (p.168) ${ }^{18}$.

16 Se define el concepto como "el conjunto de repertorios culturales interiorizados (representaciones, valores, símbolos), a través de los cuales los actores sociales (individuales o colectivos) demarcan sus fronteras y se distinguen de los demás en una situación determinada, todo ello dentro de un espacio históricamente específico y socialmente estructurado" (Giménez, 2000, p. 54).

17 La identidad cultural puede ser definida por vías de centrar a los individuos en relación con un espacio geográfico o cosmológico, a pesar de que en cada sociedad elementos diferentes pueden crear mitos diferentes del ser y la identidad cultural pueden ser con frecuencia enfrentados. La identidad cultural no debe ser separada de otras formas de identidad social (traducción propia).

18 Los espacios tienen diferentes significados para diferentes grupos, y cada espacio puede, a través del curso de un día, una semana o más tiempo, ser ocupados por una serie de diferentes grupos sociales cuyas prácticas incluyen los mismos espacios con diferentes significados en diferentes tiempos (traducción propia). 
La domesticidad, de acuerdo con Milnor (2010), se convierte en un poderoso instrumento usado por los primeros emperadores romanos para representar la feminidad y los roles asociados a las mujeres, señalando como una virtud imperial la domesticidad junto a las virtudes cívicas que Augusto impulsó durante su reinado. De acuerdo con la autora citada:

[...] by taking the responsibility for creating and maintaining the household out of the hands of individual men and instead making it part of the business of the state, the law makes a statement about the relationship between domestic and civic life, and how certain actions apply to each sphere (p. 154) ${ }^{19}$.

Las convenciones sociales en relación con el hogar y el espacio público eran dictadas por las normas y valores de la sociedad en Roma:

In the literal Latin sense, it was the relationship with (male) citizen status which made public space public: publicus derives from populus, the citizen body. The word 'public' in English can be glossed as something like 'related to everyone'. In Latin, however, the primary meaning of publicus is 'related to the populus', to the correctly constituted group of Roman adult male citizens. So what relationship could non-citizens, non-adults, non-Romans, nonmales have with public space? (Rusell, 2011, p. 169)20.

El género en el mundo romano (Scott, 1986) funciona en relación con otras categorías edad, clase o estatus social, profesión, religión y etnicidad, que contribuyen a conformar la identidad de los sujetos. La identidad se encuentra asociada a estos factores, de manera que las relaciones sociales también se encuentran relacionadas con los medios a través de los cuales se articula el ejercicio del poder. La marginalidad se encuentra determinada por elementos ligados a los elementos supra citados.

El "ius civitatis", la ciudadanía romana, suponía una serie de ventajas en el orden público y en el privado para aquellos que la poseían. En la antigüedad romana, según comentan Frier y McGinn (2004), los varones para gozar de los derechos inherentes al ius civitatis debían ser ingenui (libres) y sui iuris (no estar sometidos). En la Roma imperial para poder ser considerado como persona física ${ }^{21}$ se necesitaba tener el status libertatis (ser libre), el status civitatis (ser ciudadano) y el status familiae (no estar bajo ninguna potestad). La condición del ciudadano romano se manifiesta además en el nombre triple que ostentaban: praenomen, nomen gentilicium y cognomen. A las mujeres se las denominaba por el nombre de la gens en femenino, es decir por el nomen.

Los varones latinos que ostentaban la ciudadanía ocuparon el espacio político mediante el cursus honorum, con sus diversas magistraturas. Las mujeres, al estar fuera de este espacio material y simbólico, fueron situadas en la otredad. En el siglo I a. C., en el entorno romano,

19 “[...] al tomar la responsabilidad de crear y mantener el hogar fuera del alcance de los hombres individuales y en su lugar convertirlo en parte de los asuntos del estado, la ley hace una declaración de la relación entre la vida doméstica y cívica, y como ciertas acciones se aplican a cada esfera” (traducción propia). En un sentido literal del latín, era la relación con (varón) el estatus de ciudadano la que hacía público el espacio público: publicus deriva de populus, el cuerpo de ciudadanos. La palabra 'público’ en inglés puede ser glosado como "relacionado con todos". En latín, sin embargo, el sentido primario de público es "relacionado con el populus", referido al grupo constituido por ciudadanos varones adultos romanos. Así que cuál relación podrían tener los no-ciudadanos, no-adultos, ¿no-romanos no-varones con el espacio público? (traducción propia).

21 La categoría de persona o status personarum u hominum estaba determinado por la situación del status libertatis, el stats civitatis, el status familiae. La capitis deminutio era la falta de uno de estos estatus lo cual incidía en la capacidad jurídica pues no es considerada como tal quien no tiene libertad o ciudadanía (Arias, 1986). 
los roles de género ubicaron a las mujeres romanas en un lugar secundario de la sociedad. Si bien es cierto, algunas de ellas podían ser consideradas ciudadanas, todas carecían de derechos como el "ius sufragii" (derecho a votar en los comicios) y el "ius honorum" (derecho a ejercer las magistraturas) ${ }^{22}$. Mientras los varones poseían todos los derechos jurídicos y políticos, ellas tenían el status libertatis, pero estaban sometidas a la autoridad del paterfamilias.

Las ciudadanas romanas tenían un estatus limitado que les impedía ejercer los officia virilia (derechos masculinos) y por ende carecían de la capacidad para acceder a la esfera de privilegios cívicos. En relación con el tema, Guettel (2004) afirma: "Males achieved citizenship by birth and service, but a woman's status depended on her father's" (p. 4) ${ }^{23}$. La posición social de las latinas estaba determinada desde su nacimiento por la clase social y las relaciones de parentesco con los varones. El padre era la máxima autoridad en el hogar, poseía el derecho de vida y muerte sobre los miembros de la familia. Las féminas cumplían la función de materfamilias y su espacio de acción estaba limitado al hogar bajo la supervisión del paterfamilias.

En la escala jerárquica, el estatus jurídico del ciudadano romano, comenta Jones (2008), existía de forma reducida para los peregrini ${ }^{24}$, cuyas capacidades políticas estaban limitadas. En cuanto a los bárbaros, estos eran aquellos que no tenían las condiciones para adoptar el régimen de ciudadanía. La etimología de la palabra bárbaro tiene raíces en el mundo griego $^{25}$ y designó concretamente a los habitantes de territorios no helenos. En Roma se adoptó su uso y conservó un carácter peyorativo asociado a los pueblos no civilizados.

En la antigüedad, los factores étnico-geográficos de Roma determinaron las creencias y proyecciones asociadas con los bárbaros de un modo similar a los griegos. La lengua y la geografía definieron la pertenencia al mundo civilizado. Para los romanos, aquellos pueblos que no formaban parte del Imperio carecían de los valores culturales, educativos y sociales de Roma. Por lo tanto, los bárbaros fueron considerados extranjeros por los romanos; estos últimos, como bien enfatiza Novillo (2018), se posicionaron desde dos puntos convergentes en relación con los extranjeros:

una definición dinámica, resultado de la interacción de dos puntos de vista: uno neutro -extranjero es aquel que es originario de otro país- y uno negativo - extranjero es aquel que no forma parte del grupo político y social en relación al cual es adjudicado el estatuto (p. 4).

En Ulpiano se señala: Feminae ab omnibus officiis civilibus vel publicis remotae sunt et ideo nec iudices esse possunt nec magistratum gerere nec postulare nec pro alio intervenire nec procuratores existere. D. 50.17.2 pr. (Ulpianus libro primo ad Sabinum). Women are excluded from all civic and public duties (officia civilia vel publica), and so they cannot be judges (iudices), hold magistracies, bring legal claims for others (postulare), represent others in court, or act as procuratores (for others in lawsuits) (Frier y McGinn, 2004, p. 457).

23 Los hombres adquirían la ciudadanía por nacimiento y servicio, pero el estatus de una mujer dependía de su padre (traducción propia).

24 El peregrinus era el extranjero aceptado e integrado en el orbe romano y por consiguiente radicalmente contrario al bárbaro (Novillo, 2018).

25 El término griego $\beta \alpha ́ @ \beta \alpha \varrho o \varsigma$ se usó para referirse a los pueblos que no hablaban griego y constituía una reduplicación onomatopéyica, $\beta \alpha \varrho \beta \alpha \varrho$ (bar bar) que imitaba el sonido de otras lenguas no conocidas. El término evolucionó para designar a los extranjeros En Roma latín "barbărus" evolucionó para designar como bárbaro a todos aquellos pueblos que no estaban bajo el dominio romano. 
En este aspecto es importante resaltar que "la construcción de bordes engendra un sentido en la gente de estar en el lugar apropiado o fuera de lugar" (Storey, 2001, p. 146). La segregación establecida socialmente, en relación con la ciudadanía romana, creó un borde que separaba jurídica y socialmente a bárbaros y romanos.

El no lugar o el lugar fuera del centro es el espacio donde se inscribe lo marginal. Un espacio simbólico donde las relaciones de género, etnia, sexo y sus representaciones textuales presentan una identidad creada por los grupos que detentan y ejercen el poder político. En este sentido, como afirma Mirón (2014), las diferentes instancias de relación social y las estructuras de poder necesitan organizarse espacialmente de manera material y simbólica.

En los textos ficcionales de la antigüedad, el espacio imaginario se inscribe en el espacio social, donde es negociado en función de género y estatus social. Así, se convierte en un modelo de conducta en su dimensión topológica en la construcción de las estructuras en el espacio social. Meyers (2003) afirma: "Fictional (and other) texts are ineluctably positioned by the very fact of their narration, they become "sites of struggle" among genders, classes, ethnicities, cultures, etc., which both writers and readers "chart" (p. 47)

En el mundo antiguo romano las mujeres fueron consideradas como el otro, en función de una división establecida a partir de una división sexo-género, la cual determinó los espacios de acción de las mujeres y los varones. Ellas, como otredad, adoptaron una identidad que les fue impuesta en función de las normas y el orden social. Al respecto, como señala Bauman (1993), la noción de otredad es central para la forma como las sociedades establecen las identidades sociales. Estas últimas no son naturales, sino que representan el orden social normativizado, a partir de la jerarquía que ejercen ciertos grupos considerados como superiores a otros en el ámbito social.

Los autores latinos, con frecuencia, como afirma Foxhall (2011): “[...] apply combination of male and female attributes to an individual in order to prove a point or to make the Roman audience more or less sympathetic to him or her" (p. 46) ${ }^{27}$. Por su parte D'Ambra (2007) enfatiza la importancia de los valores romanos representados en los personajes femeninos. Por esta razón, personajes como Medea resultaban idóneos para representar los excesos nefastos de cuando una mujer transgredía los límites sociales: "Roman authors apparently struggled with the correct way to account for a powerful, authoritative matron who was by her very nature, a contradiction for a society in which a good woman was to be modest, demure, and dutiful" (p. 143) ${ }^{28}$.

Lo anterior no era negativo en las representaciones femeninas cuando se narraban acciones de mujeres fuertes como la emperatriz Livia, para citar un ejemplo. No obstante, el personaje de Medea reinterpretado en Roma, por Ovidio y Séneca, posee una caracterización más allá que la de una mujer de carácter fuerte y decidido. Ella es un elemento disruptor y perturbador de la normatividad y el orden.

26 Los textos ficcionales (y otros) son ineluctablemente posicionados por el mismo hecho de su narración, se convierten en "espacios de lucha" entre los géneros, clases, etnias, culturas, etc, las cuales son mapeadas por escritores y lectores (traducción propia).

27 [...] aplica la combinación de los atributos femeninos y masculinos a un individuo para probar un punto o para hacer que la audiencia romana fuese más o menos empática hacia él o ella (traducción propia). Los autores romanos aparentemente luchaban con la forma correcta para mostrar a una matrona poderosa y autoritaria, quien por su misma naturaleza era una contradicción para la sociedad en la cual una buena mujer debía ser modesta, recatada, y diligente (traducción propia). 
Al respecto, resulta interesante destacar la percepción de Scott (1986) sobre la caracterización femenina de los autores latinos: "they often characterized female leaders with masculine attributes to display them as usurpers of masculine Roman authority" (1986, p. 1067) ${ }^{29}$. En esta misma línea, Monserrat (2000) señala la importancia de este elemento: "the process of transforming anatomical sex into a cultural category (gender) is primarily concerned with creating "meanings about power" along with the creation and maintenance of power hierarchies" (p. 155) ${ }^{30}$. En este sentido, es importante recordar que la identidad se construye por medio de procesos subjetivos interiorizados, asimilados a partir de una identificación que diferencia al individuo de los otros, pero que a la vez lo identifica con las características que estos les asignan.

\section{Medea en los textos literarios de Ovidio y Séneca}

\subsection{Medea en las Metamorfosis de Ovidio}

Ovidio, en las Metamorfosis (8 d. C.), desarrolla una épica mitológica en la cual reúne y reescribe los mitos griegos y romanos, desde la formación del cosmos hasta la apoteosis de Julio César. Uno de los temas que usa como modelo del mundo griego es el mito de Medea y Jasón. El autor desarrolla este mito en las Metamorfosis VII, I, 424; en la primera parte del poema presenta a la joven de la Cólquide enamorada y víctima de una pasión irracional. Medea es incapaz de dominar las emociones que experimenta. La joven doncella se debate entre el deber y el amor (Ovidio, 1981, libro VII, capítulo I, vv. 18-21):

\footnotetext{
'quid faciam, video: nec me ignorantia veri decipiet, sed amor.

si possem, sanior essem!

sed trahit invitam nova vis, aliudque cupido,

mens aliud suadet: video meliora proboque,

deteriora sequor ${ }^{31}$.
}

La princesa es una víctima del poder arrasador de la pasión. Al respecto advierte Newlands (1997):

Medea emerges in the first part of Metamorphoses 7 not as being with supernatural powers that can control the universe, but as a struggling young girl who knows what is "right" but is impelled by her passion to act otherwise (p. 183$)^{32}$.

Las referencias al asesinato de Creón y su hija, así como el infanticidio en Corinto, son breves, pero se incluyen para recordar al lector los excesos de Medea (Ovidio, 1981, libro VII, vv. 396-398):

29 Ellos con frecuencia caracterizaron a las mujeres líderes con atributos masculinos para mostrarlas como usurpadoras de la autoridad masculina romana (traducción propia).

30 El proceso de transformar el sexo anatómico en una categoría cultural (Género) es en primera instancia una preocupación de crear "significados sobre el poder" junto con la creación y mantenimiento de las jerarquías de poder (traducción propia).

31 Qué haré, veo, y no a mí la ignorancia de la verdad me engañará, sino el amor. Si pudiera más sana estaría.Pero me arrastra, involuntaria, una nueva fuerza, y una cosa deseo,la mente de otra me persuade. Veo lo mejor y lo apruebo, lo peor sigo (Ovidio, 2004).

32 Medea emerge en la primera parte de la Metamorfosis 7 no como un ser con poderes sobrenaturales que puede controlar el universo, sino como una joven doncella que se debate entre lo que sabe que es "correcto" pero que está incitada por la pasión para actuar de otra forma (traducción propia). 
sed postquam Colchis arsit nova nupta venenis

flagrantemque domum regis mare vidit utrumque

sanguine natorum perfunditur inpius ensis,

ultaque se male mater Iasonis effugit arma ${ }^{33}$.

En el texto no se menciona la traición de Jasón, sino que se prioriza el recuerdo del asesinato de los niños para enfatizar el carácter cruel de la hechicera. No obstante, en la segunda parte del texto, Medea reaparece como una joven conocedora de ensalmos y rituales mágicos, con poderes sobrenaturales que la alejan de las mujeres comunes. Este elemento, si bien pertenece al mito desde sus orígenes, es retomado por Ovidio para oscurecer la figura de la mujer extranjera. El poeta narra la hechicería, los asesinatos y la venganza de la "bárbara" que ejecuta "mille aliis postquam sine nomine rebus" (1981, libro VII, v. 275), "mil cosas sin nombre", la asesina de Pelias: "cum verbis guttura Colchis abstulit et calidis laniatum mersit in undis" (1981, VII, vv. 348-349), "junto con sus palabras la garganta la cólquide le cortó, y despedazado lo sumergió en las calientes aguas" (Ovidio, 2004). Las habilidades, las palabras y las acciones sobrehumanas que Medea realiza provocan el desorden social y político.

Smith (1995) afirma que la magia se constituye en "una categoría intercultural de primer orden: toda sociedad parece tener un término o términos que designan algunas formas de actividades rituales y creencias consideradas peligrosas, ilegales o desviadas” (p. 17). El orden social en Grecia y Roma estableció espacios delimitados para los cultos religiosos y en este espacio las mujeres tenían un lugar como profetisas de la religión oficial en los oráculos. No obstante, al margen de esta religión oficial se encuentra la magia como una práctica popular, situada en la periferia y ligada a la superstición. La magia como tópico literario es un elemento acorde con las nuevas influencias del mundo helenístico en el contexto romano.

Ovidio, en Metamorfosis, relata cómo la mujer de la Cólquide con engaños traicionó a Eetes, asesinó a Pelias, intentó engañar a Egeo y matar a Teseo por medio de palabras, ensalmos y pociones (libro VII, capítulo I, vv. 297-306):

\footnotetext{
Neve doli cessent, odium cum coniuge falsum

Phasias adsimulat Peliaeque ad limina supplex

confugit; atque illam, quoniam gravis ipse senecta est,

excipiunt natae; quas tempore callida parvo

Colchis amicitiae mendacis imagine cepit,

dumque refert inter meritorum maxima demptos

Aesonis esse situs atque hac in parte moratur,

spes est virginibus Pelia subiecta creatis,

arte suum parili revirescere posse parentem,

idque petunt pretiumque iubent sine fine pacisci ${ }^{34}$.
} rey en llamas, la criminal espada se baña con la sangre de los hijos y, vengándose ferozmente, la madre escapa de las armas de Jasón. (Ovidio, 2004). umbrales suplicante huye, y a ella, puesto que abrumado él por la vejez está, la reciben sus nacidas; a las cuales la astuta cólquide, en un tiempo pequeño, de una amistad mendaz con la imagen, atrapa, y mientras relata entre los máximos de sus méritos haber quitado a Esón la decrepitud y en esta parte se demora, la esperanza ha introducido entre las vírgenes de Pelias creadas, de que por arte pareja rejuvenecer podría el padre suyo, y esto buscan, y un precio le ordenan que sin límite pacte (Ovidio, 2004). 
En la época de Augusto, comenta Simon (2001), fue cuando se consolidaron las premisas jurídicas para acusar y llevar a juicio a los que practicaban la astrología y la magia ${ }^{35}$. De acuerdo con el autor, existió un alto porcentaje de mujeres acusadas de crímenes de magia, similar al de los varones, a pesar de su no participación en asuntos políticos:

parece ilustrar claramente la relación específica que se establece entre la magia y el género femenino también en el terreno del derecho, relación no sorprendente a tenor de la consideración general de la magia como una inversión del sistema religioso, en el que los actores son casi exclusivamente hombres (p. 117).

En Roma esta práctica fue considerada socialmente como un elemento negativo originario de Oriente, una amenaza al sistema de valores del Mos Maiorum. En relación con la magia, Smith (1995) señala que es: "ante todo, un instrumento de descalificación social de aquellas creencias y prácticas consideradas ilegítimas” (pp. 190-207).

La representación de las figuras que ejercen la hechicería se asocian al mal y a rasgos negativos de la naturaleza humana alejados de la moral y las normas de la sociedad. Al respecto, Simon (2001) señala, que los magoi persas, al practicar ritos desconocidos para los romanos, fueron considerados como extranjeros, bábaros iniciados en artes secretas consideradas ilegales. Ellos eran una alteridad que atentaba contra el sistema de la civitas al oponerse a la figura del magistrado sacerdote, garante del orden religioso. La religión oficial romana representó el centro, mientras que las prácticas mágicas se asociaron a la superstición y la marginalidad.

Las hechiceras de la antigüedad greco-romana, al pertenecer a un espacio geográfico límite, como lo es la región de Tesalia o el Mar Negro, son separadas del mundo civilizado. Estos territorios son considerados en la antigüedad, de acuerdo con Luck (1985), como países situados en los confines del mundo conocido, lugares geográficos alejados y asociados con culturas bárbaras.

En el texto ovidiano, las prácticas de hechicería de Medea la ubican al margen de lo socialmente aceptado para las mujeres. El poeta relata con detalle los rituales que la maga de la Cólquide realiza con ayuda de Hécate para sus encantamientos (Ovidio, 1981, libro VII, capítulo I, vv. 200-206):

\footnotetext{
concussaque sisto

stantia concutio cantu freta, nubila pello

nubilaque induco, ventos abigoque vocoque,

vipereas rumpo verbis et carmine fauces,

vivaque saxa sua convulsaque robora terra

et silvas moveo iubeoque tremescere montis

et mugire solum manesque exire sepulcris! ${ }^{36}$
}

La princesa de los colcos tiene el poder de hacer volver los ríos hasta las fuentes, agitar o detener al mar, dominar las nubes y los vientos, mover las rocas, hacer temblar a los montes

35 Sin embargo, desde las Leyes de las XII Tablas existía una normativa contra los crimina magiae que fue complementada por leyes posteriores como la lex Cornelia de sicariis e veneficiis y la lex Iulia Maiestatis.

36 y agitados calmo, y quietos agito con mi canto los estrechos; las nubes expulso y las nubes congrego, los vientos ahuyento y llamo, vipéreas fauces rompo con mis palabras y canción, y vivas rocas y convulsos robles de su tierra, y espesuras muevo y mando temblar los montes y mugir el suelo y a los manes salir de sus sepulcros (Ovidio, 2004). 
y bramar a la tierra, arrastrar la la luna e, incluso, la Aurora palidece de temor por las drogas producidas por sus hechizos (Ovidio, 1981, libro VII, vv. 207-209):

\section{te quoque, Luna, traho, quamvis Temesaea labores aera tuos minuant; currus quoque carmine nostro pallet avi, pallet nostris Aurora venenis! $!^{37}$.}

La magia y la hechicería se constituyen en un espacio marginal asociado con frecuencia a las mujeres, los bárbaros y las clases sociales bajas. Las brujas como Medea se constituyeron en exempla míticos de los comportamientos asociados ligados a la feminidad negativa. En este sentido, como bien apunta Todorov (1991), los modelos míticos nos permiten acercarnos al otro que nos define por oposición. En el caso concreto de la hechicería, ya desde los textos literarios homéricos se sitúa a las brujas como otredad.

Los rituales y encantamientos en la literatura romana se identifican con personajes paradigmáticos que incluyen mujeres anónimas de baja clase social, o personajes míticos que realizaban ritos macabros (Canidia y Sagana en Horacio, Medea en Ovidio y Séneca, Ericto en Lucano). Los carmina que ella pronuncia muestran el poder de sus palabras: "as carmina her incantations are connected with poetry, which in the ancient world is primarily a male activity. The female appropriation of carmina is threatening to social order"38 (Newlands, 1997, p. 207). Así, el poder de su discurso no solo tiene tintes mágicos, sino retóricos por la persuasión que logra en sus oyentes.

En la antigüedad, los romanos, de forma similar a los griegos, se situaron territorialmente como un centro geográfico, simbólico y cultural. A partir de esta delimitación, se definió la normatividad y el orden social civilizado en contraste con los otros, denominados bárbaros. El protagonismo del personaje es visto bajo una luz negativa, por el poder que este posee para dominar los elementos de la naturaleza. Los poderes mágicos de Medea la sitúan en un espacio liminal. Es valorada como alteridad por la connotación negativa en relación con la hechicería, como práctica al margen de la colectividad.

\subsection{Medea en las Heroidas de Ovidio}

La obra de Ovidio sobre la epistolografía de las heroínas del mito es conocida como Heroidas. En esta obra el autor incluye la carta dirigida por Medea a Jasón. En el texto el poeta presenta una imagen de Medea más benévola que en las Metamorfosis. No obstante, el autor enfatiza el carácter peligroso, la ira sin límites y el temor que inspira la bárbara de la Cólquide. La heroida Medea a Jasón desarrolla los motivos tradicionales: la hechicería, la etnia bárbara, la traición y las acciones transgresoras de la protagonista. La joven de Colcos se casa con un extranjero y se traslada de una tierra bárbara a la civilización griega. Además, se une a Jasón, sin autorización paterna y con las manos ensangrentadas por el crimen de su hermano, traicionando todos los deberes filiales y sociales.

37 "A ti también, Luna, te arrastro, aunque de Témesa los bronces las fatigas tuyas minoren, el carro también con la canción nuestra palidece de mi abuelo, palidece la Aurora con nuestros venenos" (Ovidio, 2004). principalmente una actividad masculina. La apropiación femenina del carmina es una amenaza al orden social (traducción propia). 
En este sentido, es importante resaltar la forma en que el territorio se constituye un espacio vital en la organización espacial, social y cultural. Medea, al huir hacia la Hélade, traspasa las fronteras de su mundo y se instala en un espacio geográfico desconocido hasta entonces. La delimitación territorial posee una significación, como señala Ayala (2015), que incide en la existencia social. También Delaney (2005) afirma que los procesos de territorialización "representan mucho más que una estrategia de control espacial: implican y están implicados con formas de pensar y actuar, así como con cosmovisiones construidas y cimentadas por creencias y formas de conocer cultural e históricamente contingentes" (p. 12). Medea en los textos será valorada en función de las coordenadas antes citadas.

A lo largo de la Heroida, la esposa de Jasón relata cómo la ayuda que brindó por amor al "héroe griego" ha sido la causa de la traición cometida en contra de la patria y la familia. En este sentido resulta interesante valorar cómo el territorio, como bien comenta Ayala (2015), es un elemento fundamental para la organización espacial, social, cultural y política. Por esta razón, el autor señala la importancia del concepto al definir las relaciones sociales de los sujetos y la comunidad. Los romanos se sitúan como el centro y ubican la Cólquide en la periferia, el lugar de la otredad opuesto a la civilización. La etnia de la hechicera pertenece a territorios ajenos al mundo greco-romano.

En los textos de Ovidio y Séneca la reinterpretación del mito de Medea singulariza al personaje por su condición de extranjera, bárbara que huyó de la Cólquide por sus múltiples transgresiones (Ovidio, Medea, 1950):

\footnotetext{
Proditus est genitor, regnum patriamque reliqui;

Optima cum cara matre relicta soror;

Virginitas factast peregrini praeda latronis;

Munus, in exilio quod licet esees, tuli.

At non te fugiens sine me, germane reliqui;

Deficit hoc uno littera nostra loco;

Quod facere ausa meast, non audit scriere dextra;

Sic ego, sed tecum, dilaceranda fui. (vv. 107-116).

Quid referam Peliae natas pietate nocents

Caesaque virginea membra pateerna manu? ${ }^{39}$ (vv. 129-130).
}

En el relato de sus acciones, la heroicidad de Jasón es puesta en duda por Medea al enumerar todas las transgresiones efectuadas para favorecer al esónida. Ella las resume en un simple reclamo (Ovidio, Medea, 1950): "Vt culpent alii, tibime laudare necessest, Pro quo sum totiens ese coacta nocens" tu obligación es alabarme, por haber sido tantas veces por ti mala a la fuerza" (vv. 131-133).

El personaje de Medea no niega la autoría de los crímenes cometidos, por el contrario los acepta. Ella se asume como otredad negativa. En este punto, Morse (1998) comenta que la Medea ovidiana es diferente de la que presenta Eurípides, pues muestra una protagonista que se auto-condena por sus acciones y se juzga culpable por haber cedido a la pasión, sin respetar

39 Traicioné a mi padre, abandoné mi reino y mi patria y sobrellevé como un regalo el poder estar exilada, mi virginidad fue botín de un bandido extranjero. Pero a ti, hermano, no te dejé libre de mí al huir. En este único lugar me falla la pluma: lo que mi mano se atrevió a hacer, no se atreve a escribirlo. Así debí ser despedazada yo, pero contigo (Ovidio, Medea, 1994, vv. 107-116).

¿Para qué hablar de las hijas de Pelias, asesinas por piedad filial, y del cuerpo del padre descuartizado por mano de doncellas? (Ovidio, Medea, 1994, vv. 129-130). 
los lazos familiares. El poeta romano presenta a Medea de forma un tanto oscura por su etnia y por las prácticas de hechicería. Así, las acciones del pasado de la joven presagian una venganza aterradora contra Jasón y su nueva esposa (Ovidio, Jasón a Medea, 1950):

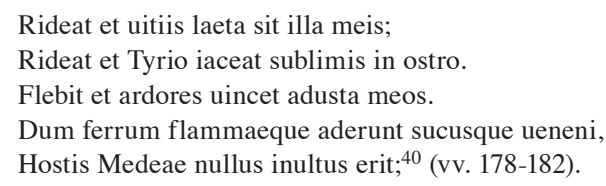

Medea, abandonada por Jasón, carece de estatus social. Los reclamos que ella enuncia no son solo quejas de la amante que sufre el abandono, sino una reivindicación del deber que él tiene hacia ella. Por esta razón, Medea denuncia la falta de heroicidad de Jasón (Ovidio, Medea, 1950):

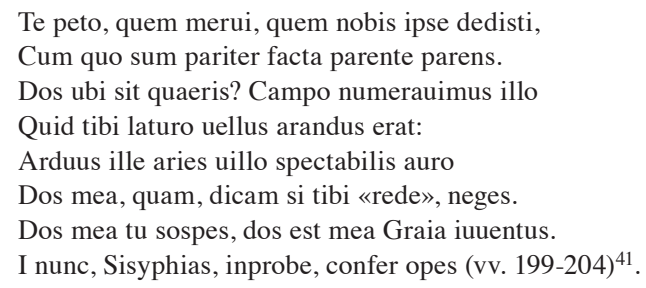

Medea le recuerda a Jasón el foedus amoris realizado por mutuo acuerdo. Si él es un "héroe" en la Hélade, es gracias al vellocino que ella le otorgó. Él no ha cumplido con las promesas y el compromiso adquirido con ella.

Si bien es cierto que el texto la representa como una mujer poderosa que opera fuera de las restricciones del mundo civilizado, el abandono del varón la ubica en el espacio de la marginalidad social. Ella tenía un estatus no reconocido como matrona por la forma irregular en la que se unió a Jasón, así, el matrimonio no era legal bajo las normas romanas. Además, la etnia la situaba como extranjera, cuyas prácticas mágicas eran contrarias a la religión oficial. Esta caracterización la posiciona en un lugar inferior dentro de la jerarquía social. Unido a lo anterior, las transgresiones que se le atribuyen -traición, engaños, fratricidio, asesinatos, hechicería y filicidio- la alejan del ideal romano de matrona virtuosa asociado inherentemente a la maternidad. La joven de la Cólquide será estigmatizada como otredad, lo ajeno, lo negativo y lo antagónico que se instala en la geografía de la Hélade y en el espacio social de Roma. Ella se constituye simbólicamente en el caos, una amenaza latente para el mundo civilizado. Newlands advierte que Medea se convierte en: “[...] the displaced woman who suffers because of the loss or lack of a husband's or lover's affection and trust and who actively seeks

40 Que se ría y que descanse altiva sobre colchas de púrpura: ya llorará y se quemará, y mayor será su fuego que el mío. Mientras no falten hierro, fuego y jugos de veneno, no quedará un solo enemigo de Medea sin su castigo (Ovidio, Medea, 1994, vv.107-116).

41 Te reclamo a ti, porque te he merecido, porque tu mismo te entregaste a mí, con quien he sido madre a la vez que tú has sido padre. ¿Preguntas donde está mi dote? La pagué con aquel campo que tú tenías que arar para llevarte el vellocino; aquel carnero de oro que con su espeso vellón se atraía las miradas es mi dote: si te dijera "Devuélvemelo" te negarías. Que tú y el ejército griego estéis a salvo es mi dote. Vamos desgraciado, compara con eso las riquezas del hijo de Sísifo (Ovidio, Medea, 1994, vv. 107-116). 
redress"42 (1997, p. 207). La princesa es consciente de la indefensión de su nueva situación. Si es difícil para cualquier mujer, es más terrible para ella, pues carece de patria y familia al ser abandonada por su marido en la Hélade (Ovidio, Medea, 1950):

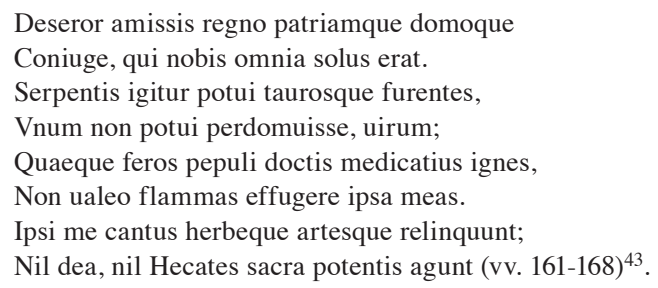

Así, la poderosa maga se siente impotente al ser abandonada vilmente por el pérfido Jasón. El amor la doblegó ante el griego en la Cólquide, ahora en Corinto es abandonada por él y ni siquiera la magia puede ayudarla en la situación presente. En el epílogo de la carta, Medea se despide de Jasón con amenazas veladas que anticipan el desenlace fatal, ya conocido por los lectores de la época (Ovidio, Medea, 1950):

\footnotetext{
Quos equidem actutum... Sed quid praedicere poenam

Attinet? Ingentis parturit ira minas.

Quo ferret ira, sequar. Facti fortasse pigebit;

Et piget infido consuluisse uiro.

Viderit ista deus, qui nunc mea pectora uersat.

Nescio quid certe mens mea maius agit (vv. 207-215) ${ }^{44}$.
}

Las amenazas encubiertas al final de la carta enfatizan el carácter irracional y las emociones desenfrenadas que caracterizan al personaje. Las palabras de Medea presagian actos innombrables, la figura de la aposiopesis, en este caso en particular enfatiza lo que el mito y la tradición consideran un acto atroz: la muerte de Creusa y Creonte, pero más terrible aún, el asesinato de los niños a manos de su madre.

Al respecto, O’Higgins (1997), citado en Newlands (1997), comenta sobre el temor que inspira la mujer de la Cólquide: "Medea most fully exemplifies the potential disloyalty present in all wives, living as necessary but suspect aliens in their husband's houses" ${ }^{45}$ (p. 122). La mujer de la Cólquide reafirma con su acto antinatural su etnia-bárbara carente de instinto maternal. Al respecto, Novillo (2018) señala:

42 " “...] la mujer desplazada que sufre a causa de la pérdida o la falta de un marido o amante la pérdida del afecto y confianza y quien de forma activa busca una compensación” (traducción propia).

43 Cuando he perdido mi reino, mi patria y mi casa, me abandona mi esposo, que era él solo todo para mí. Así que yo, que pude doblegar serpientes y toros enloquecidos, lo único que no pude doblegar fue a mi marido. Yo que combatí fuegos desaforados con sabios brebajes, no puedo huir de mis propias llamas. Me abandonan mis sortilegios, mis hierbas y mis hechizos. Nada hace la diosa (Ovidio, Medea, 1994). Yo a estos no tardaré en... ¿pero a qué viene anticipar su castigo? Mi ira está preñada de amenazas descomunales. Me dejaré llevar por la ira Mi ira está preñada de amenazas descomunales. Me dejaré llevar por la ira. Quizá tenga que arrepentirme de lo que haga; también me arrepiento de haber protegido a un marido infiel. El dios que ahora ocupa mi pecho sabrá lo que hace; lo cierto es que mi corazón trama algo espantoso (Ovidio, Medea, 1994). Medea plenamente ejemplifica el potencial la deslealtad presente en todas las esposas, viviendo como necesarias, pero a su vez extranjeras sospechosas en las casas de sus maridos (traducción propia). 
la noción de "bárbaro" nos remite más a un concepto geopolítico que a un conjunto de costumbres salvajes o creencias irracionales. Para un Imperio, los bárbaros son o pueden ser todos aquellos que conforman su periferia, los extranjeros a cuyo través las élites construyen el concepto de "enemigo exterior" (p. 6).

Medea subvierte los esquemas tradicionales con un comportamiento errático que las sitúa en la marginalidad por su origen, acciones, estatus social. Ovidio omite mencionar en la carta las acciones cometidas por la joven que favorecieron a Jasón. El poeta enfatiza las acciones de la joven a partir de un deseo maligno. El atentado al amor filial que realiza a través de las péliades, recuerda la traición de Medea a los lazos familiares en la Cólquide.

Precisamente, el personaje de Medea se opone con sus acciones al ideal romano de la mater familias. Ella se aleja del rol central de las mujeres romanas y la familia al atentar contra su progenie, irrespeta al paterfamilias, el pilar fundamental de la sociedad romana. Por esta razón la mujer de la Cólquide se convierte en una amenaza para el orden. Medea se transforma en un elemento socialmente negativo o, como la califica Blondell (1999) la "extranjera transgresora por excelencia".

El personaje de Medea es construido por Séneca como una antítesis de los valores que caracterizan a la materfamilias. El ideal romano de la feminidad supone a una mujer sumisa, que cumple a cabalidad con los deberes sociales, maritales y maternales en el hogar. La mujer de la Cólquide es encasillada por los demás como una otredad separada de los griegos, los romanos y la civilizacion. La identificación étnica con la Cólquide la ubica en un espacio social que la margina por su condición de bárbara y hechicera. En este aspecto, como afirma Bartra (1992), cuando la otredad es imaginada y nombrada en singular, ese otro oculta a los otros, a la pluralidad. Se constituye, entonces, en una ilusión de la identidad como una unidad en tanto uniformidad o igualdad. En la heroida de Ovidio la protagonista es transformada en una figura aterradora por el poder y la irracionalidad de una venganza que la aliena y la sitúa al margen de la civilización.

\subsection{La Medea de Séneca}

Lucio Annaeus Séneca (4 a. C. - 65 d. C.), poeta y dramaturgo romano de principios del Imperio, escribió una tragedia o fabula crepidata $^{46}$ sobre el personaje mítico de Medea. El autor romano reelabora el tema desarrollado por Eurípides, oscurece aún más la figura de la mujer de la Cólquide. La tragedia de Séneca, a diferencia de la de Eurípides, no introduce a Medea por medio de otro personaje, sino que se inicia con un monólogo de la protagonista. La esposa de Jasón se presenta como un ser temible, feroz, colérico, capaz de cualquier acción (Séneca, Medea, acto I, vv. 45-53):

Effera, ignota, horrida,

tremenda coelo pariter ac terris mala

mens intus agitat. Vulnera et caedem et vagum

funus per artus: levia memoravi nimis.

Haec virgo feci. Gravior exsurgat dolor.

Maiora iam me scelera post partus decent.

Accigere ira, teque in exitium para

$46 \quad$ Fabula crepidata es la denominación latina para designar las representaciones dramáticas de la tragedia con tema, personajes y ambientación griega. 


\section{furore toto: paria narrentur tua} repudia thalamis ${ }^{47}$.

Esta imagen aparece ligada también con la hechicería y la magia oscura enfatizada por las invocaciones iniciales que realiza, dirigidas a deidades ctónicas. Ya desde el acto I de la tragedia, Medea es mostrada como una "bruja" capaz de invocar los poderes oscuros: así convoca a la "Hecate triformis" (v. 4), la diosa de la magia, el "noctis aeternae Chaos" (v. 9), lugar de las profundidades tenebrosas, al "Dominumque regni tristis"(v. 11) conocido como Hades, a la "Dominam fide meliore raptam" (vv. 11-12), la diosa Proserpina y también a las "sceleris ultrices Deae” (v.13), reconocidas como las Furias. "Rumpe iam segnes moras; quae scelere parta est, scelere linquenda est domus” (Séneca, 2001, vv. 54-55).

Asimismo, la protagonista narra la faceta de asesina asociada a su juventud en la Cólquide cuando resume los crímenes cometidos, y ahora la ira, el delirio y la demencia la consumen ante el abandono de su marido (Séneca, 2001, acto I, vv. 129-136):

\footnotetext{
Scelera te hortentur tua,

et cunta redeant: inclitum regni decus

raptum, et nefandae virginis parvus comes

divisus ense, funus ingetum patri,

sparsumque ponto corpus, et Peliae senis

decota aheno membra. Funestum impie

quam saepe fundi sanquinem! At nullum scelus

ira feci. Saevit infelix amor... ${ }^{48}$.
}

Por su parte, Creonte reafirma el carácter inestable y peligroso de la mujer. El rey de Corinto la responsabiliza de la traición y los crímenes causantes de todos los males y desgracias. Por contraste, el gobernante considera a Jasón como una víctima más en la lista de Medea. La culpa recae entonces sobre la extranjera malvada, cuya astucia se refleja en sus acciones aterradoras (Séneca, 2001, acto II, vv. 179-181):

Medea, Colchi noxium Aeetae genus,

animosque minué: tempori aptari decet.

... Molitur aliquid: nota fraus, nota est manus ${ }^{49}$.

Ahora en su plenitud de mujer desea acciones más nefastas y aterradoras. De forma similar a Eurípides, el personaje de la nodriza describe la furia de Medea y la asocia con la locura al compararla con las bacantes, este comportamiento la aliena aún más y la separa de las mujeres que la rodean (Séneca, 2001, acto III, vv. 382-390):

47 Mi mente está tramando un crimen fiero, ignoto, pavoroso que hará temblar al cielo y a la tierra. las heridas, la muerte, El esparcir los miembros del cadáver serán recuerdos nimios y livianos. Esos fueron mis hechos de doncella. Surja el furor ahora más ardiente. ¡Ahora que soy madre, quieren mis manos crímenes mayores! ¡Corazón, monta en cólera! ¡Vístete de furor para esta ruina! ¡Cuéntese mi repudio como ejemplo No inferior a mis bodas! (Séneca, 2001).

$48 \quad ¡$ Mis maldades me animen! Vengan todas juntas a mi memoria: la gloria ilustre arrebatada al reino, el cuerpo de mi hermano, que nefanda dividí con la espada, mortal congoja que inferí a mi padre; el cadáver sembrado por el ponto, y los miembros ancianos del rey Pelias cocidos en el bronce, y la funesta sangre que tantas veces derramé, malvada. A todos estos crímenes me movió la ira. Pero ahora, el amor infeliz pide venganza (Séneca, 2001).

49 "Medea, hija malvada de Eetes, el de la Cólquide" ... "Notorios son sus fraudes y crímenes" (Séneca, 2001). 
Incerta qualis entehos cursus tulit, cum iam recepto Maenas insanit deo... Pindi nivalis vértice aut Nysae igugis, talis recursat huc et huc motu effero, furoris ore signa lymphati gerens. Flammata facies spiritum ex alto citat. Proclamat. Oculos uberi fletu rigat.

Renidet. Omnis specimen afectus capit.

Haeret, minatur, aestuat, queritur, gemit ${ }^{50}$.

La mujer de la Cólquide viola los límites jurídicos y políticos al asesinar por medio de hechizos y engaños. Ella actúa al margen de las convenciones sociales. La malicia característica atribuida al género femenino es la causa de que la hechicera se aleje de toda convención social, para erguirse como una otredad transgresora en los espacios civilizados. Medea, como comenta Bernal (2002), cumple una función didáctica al mostrarse como figura de contraste en relación con la cultura greco-latina, la cual se encuentra ligada a un sistema de valores similar: "Ella pertenece a otra cultura, a una raza salvaje, a un pueblo inculto, a un mundo diferente con otros valores y otras normas de conducta" (p. 478). La nodriza teme las acciones nefastas que Medea es capaz de realizar (Séneca, 2001, acto III, vv. 393-395):

Non facile secum versat aut medium scelus.

Se vincet:irae novimus veteres notas.

Magnum aliquid instat, efferum, immane, impium ${ }^{51}$.

La maldad de la protagonista transgrede la imagen de madre al anunciar, refiriéndose a la muerte de sus hijos: "Abdico, eiuro, abnuo!", "Reniego de ellos, renuncio a ellos, no los reconozco" (Séneca, 2001, v. 507). Paraíso (1988) resalta cómo Séneca convierte a Medea en una "[...] bacante furiosa poseída por la sed de venganza", "[...] una mujer perversa, se sabe perversa y se proclama perversa. [...] Medea habla de su crueldad y de su locura como si fueran timbres de gloria" (p. 311). Ella es una mujer fuera de todo control, en sus hijos encuentra el instrumento para vengarse del héroe al reconocer que este los ama.

La progenie se convierte en el punto débil de Jasón y, Medea, al planear su venganza final, se identifica con madres asesinas del mito: "Piae sororis, impiae matris facem, ultricis Altheae vides", "Mira la antorcha de la hermana piadosa y fiera madre, la vengativa Altea" (Séneca, 2001, acto IV, v. 779). El autor romano va más allá y a esta imagen antinatural de materfamilias agrega la hechicería. De esta forma, convierte a Medea en una alteridad alejada de toda humanidad. Él la presenta invocando a los poderes oscuros para llevar a cabo su terrible venganza. Así, Morse (1998) define a Medea:

$50 \quad$ Cual incierta bacante, que ha emprendido fuera de sí por el divino influjo, la carrera sagrada sobre las cumbres del nevado Pindo o en las crestas del Nisa, así corre Medea de un lado a otro, con feroces pasos, llevando en el semblante las señales de un furor rabioso; y su rostro encendido arranca hondos suspiros a su pecho. Grita. Riega sus ojos con abundante llanto. Sonríe. Expresa juntas mil contrarias pasiones. Detiénese de pronto. Prorrumpe en amenazas, arde en odio. Se queja, da gemidos (Séneca, 2001).

51 "No es un simple y ordinario crimen a lo que está dando vueltas en su interior. Va a superarse a sí misma; bien conocidas tengo yo las señales de su cólera de otras veces. Se nos viene encima algo grande, inhumano, atroz, impío; estoy viendo su rostro enloquecido" (Séneca, 2001). 
[...] she is disorder incarnate,she is a woman in the grip of irrational frenzy. She is also a tragic human being in an insoluble dilema, one already known to other women, such as Procne and Althaea, each of whom sacrificed her child in order to avenge herself (p. 51) ${ }^{52}$.

Nuevamente, la nodriza es quien narra con detalle la ira que consume a la hechicera y cómo se prepara para ejecutar los rituales mágicos (Séneca, 2001, acto IV, vv. 674-684):

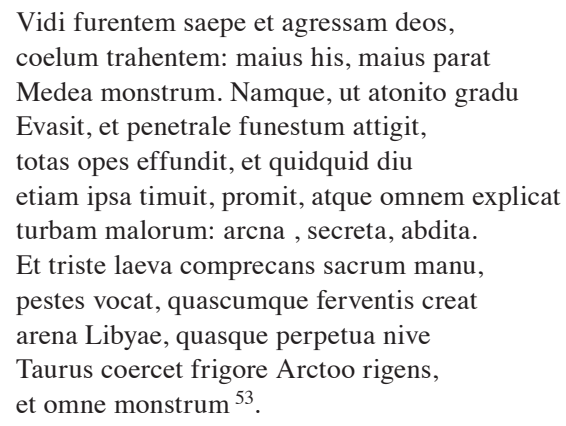

Así, a medida que avanza la tragedia, ella adquiere cada vez más un carácter tenebroso y maléfico. La mujer da paso a una hechicera malévola cuyo deleite lo constituye el sufrimiento ajeno. Séneca se encarga de mostrar a Medea cada vez más monstruosa y aterradora. La protagonista guiada por la ira, que excede todos los límites, deja de lado el pudor y lo sagrado para convertirse en una asesina sin piedad. En el texto de Séneca la hechicera de la Cólquide afirma su deseo de venganza sin límites y el poeta la asocia con la locura de las Ménades. Medea es presentada como una maga que pronuncia hechizos, ensalmos terribles, sortilegios oscuros, para dominar a la naturaleza con manos ensangrentadas, preparando pócimas y venenos atroces (Séneca, 2001, acto IV) ${ }^{54}$ :

Quodcumque tellus vere nidifico creat [...] (v. 714).

[...] quodcumque gramen flore mortifero viret,

dirusve tortis succus in radicibus

causas nocendi gignit, attrectat manu (vv. 717-718).

$52[$ [...] ira, ella es la encarnación del desorden, ella es una mujer atrapada por el frenesí irracional. Ella es también un ser humano trágico en un dilema insoluble, uno ya conocido por otras mujeres, tales como Procne y Altea, cada una de las cuales sacrificó a su propio hijo para vengarse (Séneca, 2001).

La he visto enfurecida, dirigirse a los dioses y hechizar los cielos. Pero es mayor el crimen que hoy prepara Medea. Pues, cuando hubo salido con paso enajenado y entró en la estancia lúgubre, usa todas sus artes y escoge siempre lo que ella misma temiera. Da rienda suelta a todo los males misteriosos, secretos y recónditos y hace el ensalmo fúnebre con la siniestra mano invocando las pestes que produce la arena de la abrasada Libia y las que encierra el Tauro, rígido por el frío de sus nieves perpetuas y otros muchos espantos (Séneca, 2001).

54 "Recoge ponzoñas que la tierra produce [...]" (Séneca, Medea, trad. en 2001, v. 714); “[...] las plantas mortíferas flores, o las que en sus raíces retorcidas esconden los espantosos zumos que sirven a la muerte" (Séneca, Medea, trad. en 2001, vv.717-718); "Coge hierbas mortíferas, y exprime las ponzoñas de las sierpes, y mezcla con repugnantes aves el corazón del búho, que augura cosas tristes, y las frescas entrañas de la ronca lechuza. Artífice de crímenes, coloca separados todos estos venenos. Unos tienen la fuerza de las llamas voraces; otros del frío hielo, que entumece los miembros, encierran los rigores. Añade a las ponzoñas ensalmos; no es en estos menos temible suena su paso enfurecido, y canta. El mundo tiembla con sus voces primeras" (Séneca, Medea, trad. en 2001, vv. 731-739). 
Mortifera carpit gramina, ac serpentium
saniem exprimit, miscetque eet obscoenas aves,
moestique cor bubonis et raucae striges
exsecta vivae viscera. Haec scelerum artifex
discreta ponit. His rapax vis ignium,
his gelida pigri frigoris glacies inest.
Addit venenis verba, non istis minus
metuenda. Sonuit ece vesano gradu,
canitque. Mundus vocibus primis tremit! (vv. 731-739).

La descripción de Medea en Séneca dibuja la imagen de una maga oscura, presa de la cólera con el poder y el conocimiento de "lúgubres artes". La princesa de la Cólquide tiene la capacidad de invocar males atroces, monstruos espantosos y venenos terribles. El cielo y la tierra le proporcionan los ingredientes mortíferos para elaborar venenos sin igual. Así, la hechicera es capaz de invocar las fuerzas oscuras para llevar a cabo sus planes funestos.

La representación maligna de Medea, como comenta Luque (1987), parece ser una creación original de Séneca, quien desarrolla a plenitud el desenfreno que la convierte en una ménade salvaje dominada por la irracionalidad. Por su parte, Nussbaum señala que la hija de Eetes, es considerada por el coro como: "an abnormal being, doomed to live out the fate belonging to an overly intense nature" (1997, p. 221).

Ella es una auténtica urdidora de crímenes, poderosa y vengativa que cuenta con la ayuda de divinidades de carácter ctónico que acuden a su llamado (Séneca, 2001, acto IV):

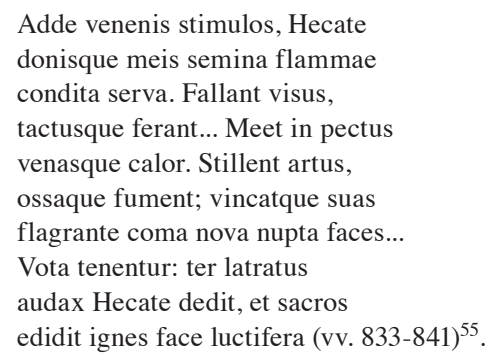

En fin, todo en Medea es exceso sin límites. La imagen de maldad presentada por el autor muestra a una bárbara que contradice el pudor, la bondad y el amor materno (Séneca, 2001, acto IV) $)^{56}$ :

\author{
Ite, Ite nati, matris infaustae genus: \\ pretiosa per quos dona nubenti feras... (vv. 845). \\ Vadite, et celeres domum \\ Referte gressus, ultimo amplexu ut fruar (vv.847-848).
}

La protagonista de Séneca se asume como alteridad y se enfrenta al orden de lo sagrado y lo moral para llevar a cabo su venganza. Ella es Medea, no se arrepiente de sus

55 Añade fuerza a mis venenos, Hécate, y conserva escondido en estos dones el germen de la llama. Engañen a los ojos y soporten el tacto... Infíltrese el ardor en sus entrañas y en sus venas. Derrítanse sus miembros; echen humo sus huesos. Con las llamas de su cabello eclipse las nupciales teas la nueva esposa... (Séneca, 2001).

56 "Vengan acá hijos: Id retoños de una madre sin ventura [...]" (Séneca, 2001, v. 845); "Id, y volved ligeros para darme vuestro postrer abrazo" (Séneca, 2001, vv. 847-848). 
acciones pasadas y las considera una antesala para vengar su humillación en el presente, rompiendo todos los esquemas sociales (Medea, acto V, vv. 889-914):

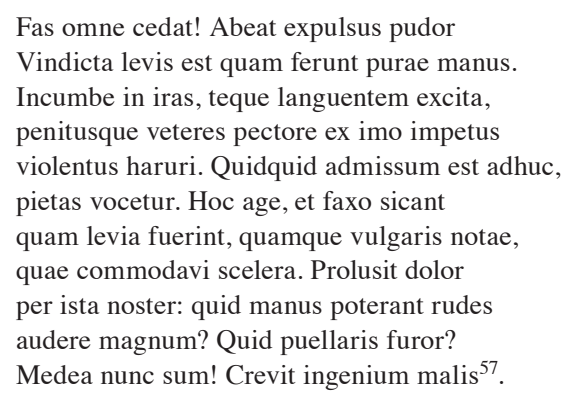

Medea expresa su deseo irrefrenable de exterminar a la progenie que engendró con Jasón. Séneca se detiene en el asesinato para mostrarnos el carácter vil de la protagonista. De este modo, el poeta lleva al límite las acciones de esta mujer para convertirla en alteridad, así ningún crimen es suficiente para satisfacer su venganza. No satisfecha con el crimen de sus hijos para herir a su marido, afirma que si acaso existe en sus entrañas un hijo no nato lo exterminará de forma salvaje (Séneca, 2001, acto V, vv. 1009-1013):

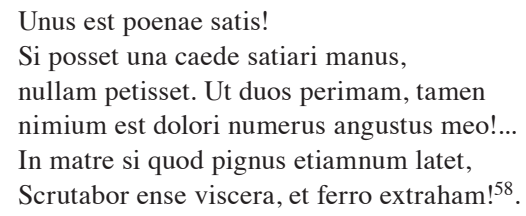

La acción que Medea propone atenta nuevamente contra los derechos del padre. El aborto en Roma, como bien lo afirma Castresana (1993), era una potestad exclusiva del paterfamilias. Además, la imagen que presenta es opuesta a todo lo que idealmente debe ser una materfamilias. Finalmente, a diferencia de la Medea de Eurípides, en donde la madre se niega a abandonar los cadáveres de sus hijos y se los lleva consigo, la protagonista de Séneca arroja los cadáveres de los niños al padre y se marcha en un carro alado guiado por serpientes (Séneca, 2001, acto V, vv. 1120-1124):

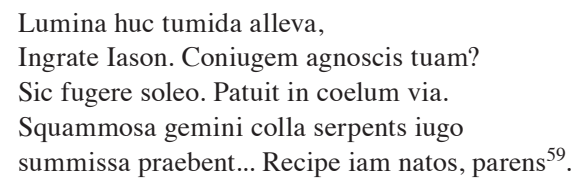

$57 \quad$ ¡Fuera todo lo justo! ¡Echa de ti el recato! Liviana es la venganza de unas manos sin crimen. Fomenta en ti la ira. No se apague tu furia. Levántese en tu pecho los ímpetus antiguos. Tus crímenes pasados ténganse por clemencia. Con éste haré que sepan cuán livianos han sido y cuán puestos en uso los que tomé prestados. Preludios, no más, fueron de mi dolor aquellos. Eran torpes mis manos para grandes hazañas, y mi furor de entonces era el de una doncella. ¡Ahora soy Medea! Creció mi ciencia en males (Séneca, 2001).

58 Aún matando a los dos, es una cifra demasiado corta para el resentimiento que yo tengo. Por si en mi vientre de madre se oculta todavía alguna prenda de nuestro amor, escrutaré con la espada mis entrañas y con el hierro lo echaré fuera (Séneca, 2001).

59 "Alza Jasón ingrato tus ojos insolentes. ¿Conoces a tu esposa? Así suelo fugarme. Me abre camino 
Este final de la tragedia pone fin al retrato de la princesa de la Cólquide elaborado por el autor latino. Desde esta perspectiva, la extranjera representa no solo la alteridad sino todo lo aborrecible que puede tener una mujer como antítesis del ideal modélico de la materfamilias romana. Así, de acuerdo con Cabrero (1997), el final de la obra de Séneca muestra a Medea como una amenaza para el patriarcado, pues se convierte en:

\footnotetext{
[...] uno de los personajes más complejos de la literatura occidental: mujer apasionada y sabia, o hechicera poderosa, como prefiramos, pero, sin duda, seductoramente independiente, dueña de sí misma, capaz de transgredir todas las normas para explorar su condición de mujer, aquella que por propia decisión coopera o abandona deliberadamente a su varón y es consciente de su capacidad única de dar y privar de la vida (p. 41).
}

Newlands (1997) señala que la muerte de los niños provoca: “Questions concerning marriage, love, betrayal, and woman's marginal status tend to be engulfed by the horror of Medea's act of infanticide"60 (p. 180). La destrucción de la relación filial entre padres e hijos, la práctica de la magia y la etnia bárbara de Medea sirven para aislarla del contexto social y geográfico romano. La mujer de la Cólquide es un agente negativo para el colectivo femenino. Ella atenta contra el instinto maternal considerado como natural e inherente de la condición femenina en la antigüedad clásica. Las carencia de tal instinto la singulariza como un ser cruel y salvaje y la sitúa en un espacio ajeno al mundo civilizado. La cultura greco-romana comparte una identidad que la ubica en espacios geográficos y simbólicos asociados al orden, las normas y la civilización. Medea es lo diferente, lo extraño que divide y causa desorden, pues en ella se proyectan los excesos sin límite de la feminidad sin control. La diferencia puede definirse como una ausencia, una falta o incluso la incompletud. En este sentido, como bien apunta Castiblanco (2017), se estigmatiza al otro, se nombra o se define a partir de algún parámetro de normalidad: "Nombramos al otro con la negación de una palabra, con la negación de su palabra. La mismidad nombra al otro para negarlo, para excluirlo; o lo nombra para que haga parte de ella, para incluirlo [...]" (p. 114). Medea existe como ausencia de identidad al no tener patria, ni familia. Ella se constituye en carencia por el comportamiento contrario a lo establecido por los límites territoriales, sociales, jurídicos, culturales y políticos del mundo antiguo.

\section{Conclusiones}

El mito literario del personaje de Medea adquiere una valoración negativa cuando traspasa límites geográficos, sociales y culturales, al huir de la Cólquide hacia la Hélade. Las acciones iniciales que relatan los poetas la muestran incursionando en el espacio míticosimbólico y material de Grecia y Roma. Ella es encasillada en el modelo arquetípico de feminidad negativa, por su condición de extranjera transgresora del orden en la sociedad. En Ovidio y Séneca, Medea no es solo un estereotipo femenino que atenta contra la normativa que regula las jerarquías de género, sino que se convierte en un motivo literario de la marginalidad impuesta en el mundo greco-romano a los extranjeros considerados bárbaros.

Los excesos de Medea, para los romanos, son propios de un espacio geográfico alejado de la civilización, en este caso la Cólquide. La etnia y las prácticas mágicas de Medea son

el cielo. Dos serpientes someten sus cuellos escamosos al yugo... Ahora padre, recibe ya a tus hijos" (Séneca, 2001).

60 Los cuestionamientos concernientes al matrimonio, el amor, la traición, y el estatus marginal de la mujer tienden a ser sepultados por el horror del infanticidio de Medea (traducción propia). 
elementos que la separan de la romanidad y la construyen como alteridad. En la Cólquide, la princesa poseía una posición de prestigio por la genealogía divina y los poderes mágicos. En este espacio geográfico, Medea era reverenciada, respetada y admirada. En la geografía grecoromana se invierte esta posición y se le ubica en la marginalidad social y fuera de la ley por sus prácticas de hechicería.

Territorialmente, Roma es el centro que determina los comportamientos y las normas frente a las cuales se juzga a los demás. Los factores étnico-geográficos y la feminidad son elementos que sitúan a Medea, como mujer bárbara, en un espacio liminal. La princesa de los colcos pierde su estatus real y debe situarse en la periferia. Ella no es ciudadana y carece de una relación reconocida socialmente con un varón. Medea, por su condición de extranjera y mujer, sufre una doble segregación. La representación de las acciones de Medea narradas en Ovidio y Séneca la unen a lo irracional, a la venganza excesiva y la pasión sin límites. Si bien es cierto que este comportamiento no es inherente ni exclusivo de la feminidad, sí se discrimina a la mujer de la Cólquide por su origen étnico-cultural. Ella como mujer, esposa, madre y hechicera, representa la barbarie fuera de control que se opone al espacio geográfico, los valores y el orden político-social de Grecia y Roma en la antigüedad.

La condición femenina polarizada en Medea se convierte en el paradigma que ejemplifica la etnia y la barbarie ubicadas en el espacio simbólico de la otredad. Medea no solo cruza límites geográficos, sino que trasciende los bordes y los límites sociales. La princesa de la Cólquide convierte el espacio fronterizo en el punto de encuentro de la civilización y la barbarie como espacios antagónicos. La feminidad se convierte en un margen, el no espacio, la liminalidad con respecto a un centro masculino civilizado. Ella surge, entonces, como una amenaza velada, la cual desde la marginalidad atenta contra el orden y la sociedad al asumirse como alteridad.

\section{Bibliografía}

Apolonio de Rodas. (1996). Argonáuticas. (M. Valverde, trad.). Madrid: Gredos.

Apollonius Rhodius. (2009). Argonautica. (W. Race, ed. y trad.). Cambridge: Harvard University Press.

Arias, J. (1986). Derecho Romano. (Vol.1). Madrid: Revistas de Derecho Privado.

Ayala, S. L. (2015). De territorios, límites, bordes y fronteras: una conceptualización para abordar conflictos sociales. Revista de Estudios Sociales, 53, 175-179. Recuperado de https://revistas.uniandes.edu.co/doi/pdf/10.7440/res53.2015.14

Bartra, R. (1992). El Salvaje en el espejo. Madrid: Era.

Bauman, Z. (1993). Bauman's Challenge: Sociological Issues for the 21st Century. United Kingdom: Palgrave McMillan.

Bernal, C. (2002). Medea en la tragedia de Séneca. En A. López y A. Pociña (Eds.), Medeas, Versiones de un mito desde Grecia hasta hoy (Vol 1) (pp. 486-509). Granada: Universidad de Granada.

Blondell, M. (1999). Women on the edge: Four plays by Euripides. New York: Routlege. 
Cabrero, M. (1997). Las voces de Medea de Christa Wolf. En A. López y A. Pociña (Eds.), Medeas: versiones de un mito desde Grecia hasta hoy (Vol 2) (pp. 1073-1103). Granada: Universidad de Granada.

Castiblanco, I. (2017). ¿Quién es el otro? [un secreto]. Saberes y Prácticas. Revista de Filosofía y Educación, (2), 1-10. Recuperado de http://revistas.uncu.edu.ar/ojs/index.php/ saberesypracticas/article/view/975

Castresana, A. (1993). Catálogo de virtudes femeninas: De la debilidad histórica de ser mujer versus la dignidad de ser esposa y madre. Madrid: Tecnos.

D’Ambra, E. (2007). Roman Women. New York: Cambridge University Press.

Del Casino, V. (2009). Social Geography. A critical introduction. United Kingdom: WileyBlackwell.

Delaney, D. (2005). Territory: A Short Introduction. Nueva York: Wiley-Blackwell.

Eurípides. (1925). Médée. Euripide. (Tome I). (L. Méridier, trad.). [Edición bilingüe]. Paris: Les Belles Lettres.

Eurípides. (1985). Tragedias. (Vol. 2). (A. Medina y J. A. López-Férez, trad.). Madrid: Gredos.

Featherstone, M., Hepworth, M. y Turner, B. (1993). The Body: Social Process and Cultural Theory. London: Sage.

Foxhall, L. (2011). Studying Gender in Classical Antiquity. Cambridge: Cambridge University Press.

Foxhall, L. y Neher, G. (2011). Gender and the city before Modernity: Introduction. Revista Gender and History, 3(23), 491-509. Recuperado de https://onlinelibrary.wiley.com/ doi/full/10.1111/j.1468-0424.2011.01662.x

Frier, B. y McGinn, T. (2004). A case on Roman Family Law. New York: Oxford University Press.

Giménez, G. (2000). Materiales para una teoría de las identidades sociales. En J. M. Valenzuela (Coord.), Decadencia y auge de las identidades (pp. 9-28). México: El Colegio de la Frontera Norte, Plaza y Valdés.

Grahame, M. (1998). Material culture and roman identity: the spatial layout of Pompeian houses and the problem of ethnicity. En R. Laurence y J. Berry (Eds), Culture Identity in Roman Empire (pp. 156-178). London: Routledge.

Guettel, S. (2004). Geography and Ethnography: Perceptions of the World in Pre-Modern Societies. United Kingdom: Wiley-Blackwellk.

Hesíodo. (1997). Obras y Fragmentos; La Teogonía. Los trabajos y los días, Escudo, Fragmentos. (A. Ortega, trad.). Madrid: Gredos.

Hesíodo. (2018). Theogony. (G. W. Most, ed. y trad). Cambridge: Harvard University Press.

Jenkins, R. (2004). Social Identity. London: Routledge.

Johnston, R. J. (2005). Makers of modern human geography: introduction to a new series. Progress in Human Geography, 29, 327-28. 
Johnston, S. y Clauss, I. (1997). Medea. New Jersey: Princeton University Press. Jones, T. (2008). Roma y los bárbaros: una historia alternativa. Barcelona: Crítica.

Lefebvre, H. (1979). Space: social product and use value. En J. W. Freiburg (Ed.), Critical Sociology: European perspectives (pp. 285-295). Nueva York: Irvington.

Lindón A. y Hiernaux, D. (2006). Tratado de Geografía Humana. México: Anthropos.

Luck, G. (1985). Arcana Mundi. Madrid: Gredos.

Luque, J. (1987). Séneca, Tragedias. [Traducción, Introducción y notas]. Madrid: Gredos.

Massey, D. (2001). Space place and gender. Minessota: University of Minnesota Press.

McDowell, L. (2000). Gender, Identity and Place. Understanding Feminist Geographies. Minnesota: University of Minnesota Press.

Meyers, S. K. (2003). Mapping Gender: Feminist cartographies in Kate Chopin-s "Regionalist" Stories. Revista de Filología y Lingüística de la Universidad de Costa Rica, 29(1), 85-101.

Milnor, K. (2010). Gender, Domesticity and the Age of Augustus: Inventing private life. London: Oxford University Press.

Mirón, M. D. (2014). Entre la casa y el ágora: género, espacio y poder en la polis griega. Aljaba, (18), 11-34. Recuperado de http://www.scielo.org.ar/scielo.php?script=sci_arttext\&pid $=$ S1669-57042014000100001

Monserrat, D. (2000). Reading gender in the Roman World. En J. Huskinson (Ed.), Experiencing Rome: culture, identity and power in the Roman Empire (pp. 153-182). New York: Routledge.

Morales, R. (2012). Medea de Eurípides, un análisis desde la perspectiva de algunas teorías modernas de la cultura. Revista de Lenguas Modernas, 17, 131-155.

Morse, R. (1998). The medieval Medea. Cambridge: D. S. Brewer.

Newlands. (1997). The metamorphosis of Ovid's Medea. En J. Clauss y S. Johnston (Eds.), Medea: Essays on Medea in Myth, Literature, Philosophy, and Art (pp. 178-208). New Jersey: Princeton University Press.

Novillo,M.(2018).Ser extranjero enla Antigua Roma. Recuperadode http://anatomiadelahistoria. com/2018/02/ser-extranjero-en-la-antigua-roma/

Nussbaum, M. (1997). The fragility of goodness. Cambridge: Cambridge University Press.

Ovidio. (1950). Heroidas. México: UNAM

Ovidio. (1981). P. Ovidi Nasonis Metamorphosen. [Edición bilingüe]. (A. Pérez, ed. y trad.). Madrid: Cátedra.

Ovidio. (1994). Cartas de las Heroínas. (A. Pérez, trad.). Madrid: Gredos.

Ovidio. (2004). Metamorfosis. (C. Álvarez y R. Iglesias, trad.). Madrid: Gredos.

Paraíso, L. (1988). Contribución a la semántica de Medea: Eurípides, Séneca, Unamuno. Oviedo: Universidad de Oviedo. 
Petts, D. (1998). Landscape and cultural identity in Roman Britain. En R. Laurence y J. Berry (Eds), Culture Identity in Roman Empire (pp. 79-94). London: Routledge.

Píndaro. (1995). Odas y Fragmentos de Píndaro. (A. Ortega, trad.). Madrid: Cátedra.

Píndaro. (1997). Olympian Odes. Pythian Odes. (W. Race, ed. y trad.). Cambridge: Harvard University Press.

Rusell, A. (2011). The definition of Public Space in Republican Rome. University of California: Berkley.

Scott, J. (1986). Gender: A useful category of historical analysis. The American Historical Review, 5(91), 1053-1075.

Séneca. (2001). Medea. [Edición bilingüe]. (V. García-Yebra, ed. y trad.). Madrid: Gredos.

Simon, F. (2001). Sobre la emergencia de la magia como sistema de alteridad en la Roma Augústea y Julio-Claudia. Revista Internacional de Investigación sobre Magia y Astrología Antiguas. 1, 105-132. Recuperado de https://www.academia.edu/38003282/ Sobre_la_emergencia_de_la_magia_como_sistema_de_alteridad_en_la_Roma_ aug\%C3\%BAstea_y_julio-claudia

Smith, J. (1995). Ancient magic and ritual powers. New York: Leiden.

Storey, D. (2001). Territory: The Claims of Space. Oxford: Pearson.

Todorov, T. (1991). Nosotros y los otros. México: Siglo XXI. 
